\title{
POISON AS CURE: A CLINICAL REVIEW OF BOTULINUM TOXIN AS AN INVALUABLE DRUG
}

\section{BALI J. (1), THAKUR R. (2)}

(1) Department of Ophthalmology, MPNS Polyclinic, Delhi, India; (2) Department of Internal Medicine, Government Medical College and Hospital, Chandigarh, India.

ABSTRACT: Botulinum toxin is the most potent toxin known. It is readily absorbed from mucosal surfaces. If dispersed as an aerosol or mixed in the food or water it can lead to a large outbreak of botulism. The disease presents as a symmetric descending paralysis in an afebrile patient. Cranial nerve involvement with diplopia, dysarthria, dysphonia, dysphagia and respiratory paralysis is seen after a variable incubation period. The treatment is mainly supportive. The source of the toxin is Clostridium botulinum, an anaerobic gram-positive spore-forming organism. Some other species of Clostridium like $C$. butyricum and $C$. baratii also produce the toxin. The toxin is heat labile and can be inactivated by heating at $100^{\circ} \mathrm{C}$ for 10 minutes. The toxin acts at the peripheral cholinergic nerve terminals at the neuromuscular junctions, postganglionic parasympathetic ganglia, etc, and affects neurotransmitter release by inhibiting exocytosis. Clinical uses in various medical fields were found for it.

KEY WORDS: Botulinum toxin, mechanism of action, botulism, therapeutics.

\section{CORRESPONDENCE TO:}

JATINDER BALI, D-10, MCD Medical Complex, Kalidas Marg, Gulabibagh, 110007, Delhi, India. Phone: 911123646081. Email: drjatinderbali@yahoo.com. 


\section{INTRODUCTION}

Botulinum toxin (BTX) is the most potent toxin known. It is readily absorbed from mucosal surfaces. Apprehensions have been expressed about its possible use as an agent in bioterrorism and biological warfare. If dispersed as an aerosol or mixed in the food or water it can lead to a large outbreak of botulism. The disease presents as a symmetric descending paralysis in an afebrile patient. Cranial nerve involvement with diplopia, dysarthria, dysphonia, dysphagia and respiratory paralysis is seen after a variable incubation period.

Clostridium botulinum was identified as the cause of botulism (6). It is an anaerobic gram-positive spore-forming organism. It is found in marine and soil environments all over the world. On the basis of antigenic specificity of its toxin, it has been divided into 7 types: A, B, C, D, E, F, and G. In addition to Clostridium botulinum, some other species of Clostridium like C. butyricum and C. baratii also produce the toxin.

Dr. Herman Sommer produced a crude form of botulinum toxin A in 1926 (22). Dr. Edward Schantz First produced purified toxin A in 1946 (20). In the late nineteen seventies, botulinum toxin was used by Dr. Alan Scott through injection into the extraocular muscles for correction of strabismus. The toxin has presented clinical uses in various medical fields (21).

\section{PHYSICAL CHARACTERISTICS}

Botulinum toxin exists in eight distinct subtypes designated as $A, B, C_{1}, C_{2}, D, E, F$, and G. They differ in biosynthesis, size, and mechanism of action. All subtypes, except $\mathrm{C}_{2}$, are capable of inhibiting acetylcholine release. $\mathrm{C}_{2}$ appears to be a lethal vasodilating toxin (8). Only toxins $A$ and $B$ (Table 1 ) have been approved by the Food and Drug Administration (FDA) for use in human beings.

Each toxin consists of a light and a heavy chain bonded together covalently by disulphide bond. These are covered by non-toxic surface proteins (18).

Table 1: Physical characteristics of toxins A and B (6).

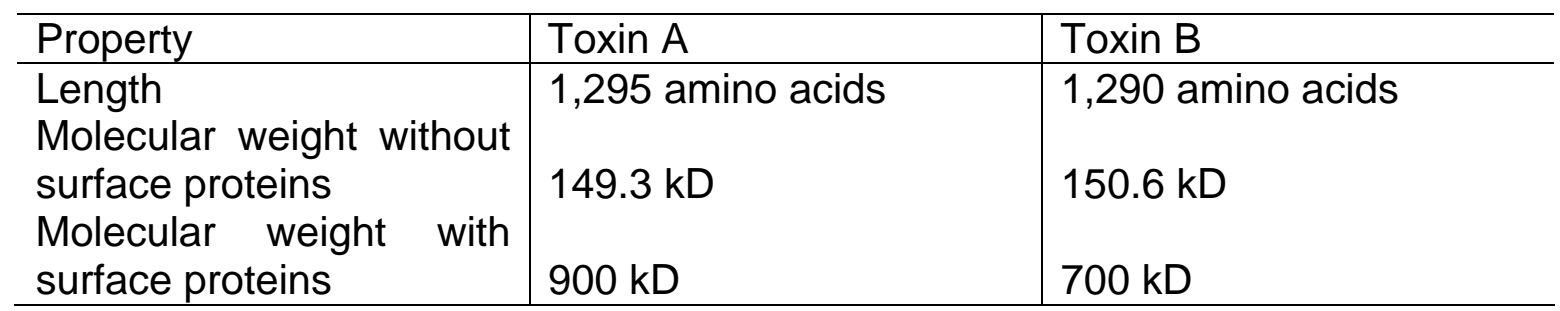


The chain is cleaved one-third from the $\mathrm{N}$-terminus to create a light chain. The light chain is bonded covalently to the heavy chain. The complex then experiences cleavage at the C-terminus of the heavy chain inside the bacterium (5). These toxins are surrounded by nontoxic surface proteins produced by the bacterium.

The toxins inhibit the release of acetylcholine at the terminals of cholinergic neurons at the neuromuscular junction. With the propagation of action potential, there is activation of membrane bound calcium channels. The increased levels of calcium cause the Synaptosomal Associated Protein Receptor (SNARE) proteins to aggregate to form complexes (Figure 1). This causes the fusion of the vesicle containing acetylcholine with the synaptic membrane. The acetylcholine is released into the neuromuscular junction (Figure 2). The toxins inhibit the aggregation and complex formation of SNARE proteins (10).
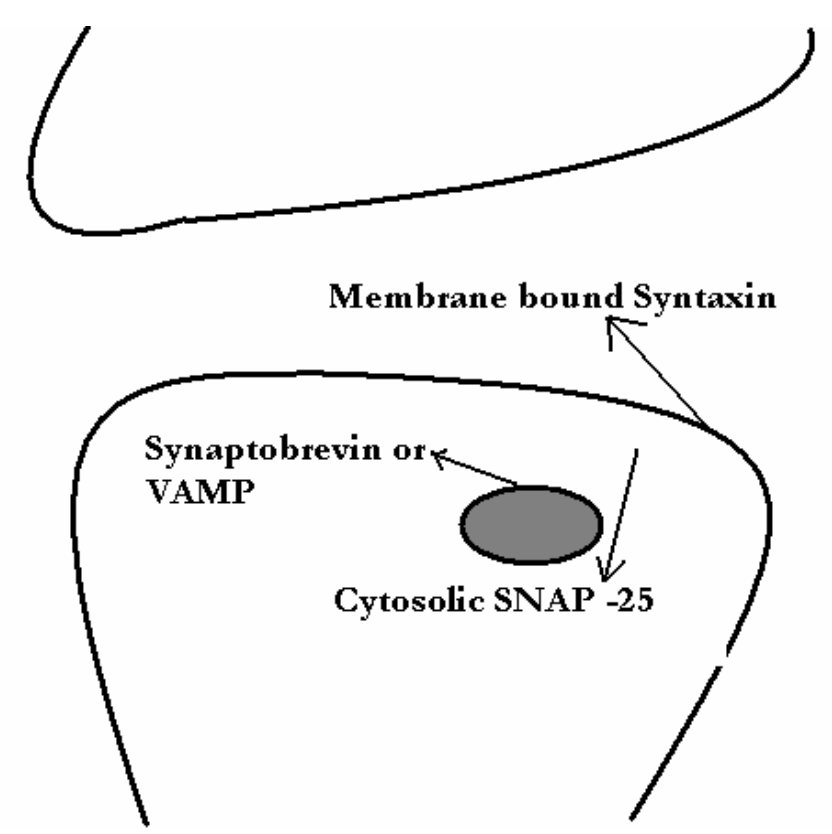

Figure 1: Synaptosomal associated protein receptor (SNARE) complex. 


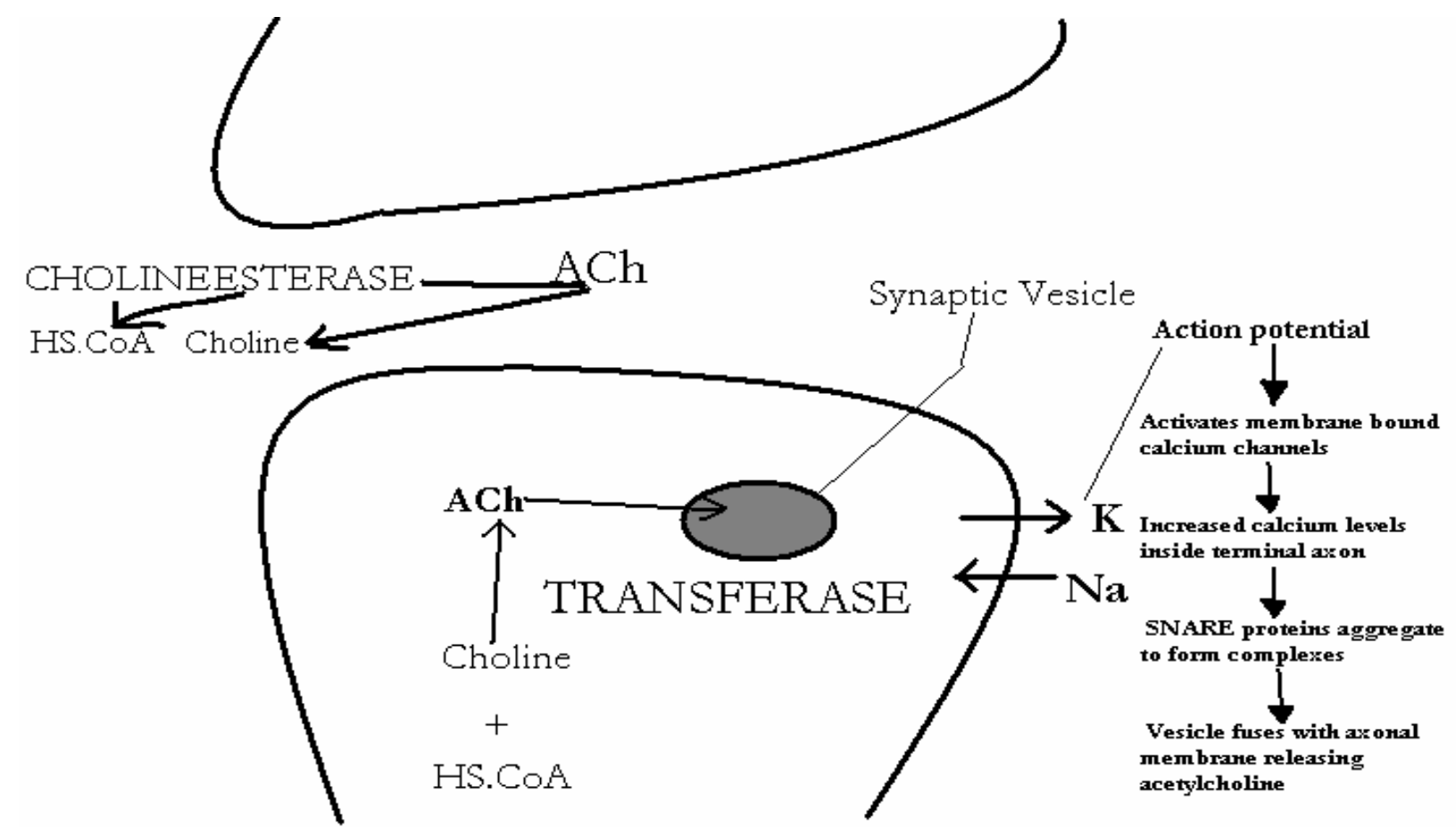

Figure 2: Mechanism of action of botulinum toxin

The SNARE complex consists of the following three proteins: Synaptosomal Associated Protein (SNAP25); synaptobrevin or Vesicle Associated Membrane Protein (VAMP); and syntaxin (Table 2).

Table 2: Components of the SNARE complex (4).

\begin{tabular}{l|l}
\hline Component & Location and composition \\
\hline $\begin{array}{l}\text { Synaptosomal Associated } \\
\text { Protein (SNAP25) }\end{array}$ & 206-amino acid cytosolic protein \\
$\begin{array}{l}\text { Synaptobrevin / Vesicle } \\
\text { associated membrane protein (VAMP) }\end{array}$ & $\begin{array}{l}\text { 120-amino acid protein in the } \\
\text { vesicle membrane }\end{array}$ \\
Syntaxin & $\begin{array}{l}\text { Docking and signaling protein in } \\
\text { the synaptic membrane }\end{array}$ \\
\hline
\end{tabular}

Each toxin serotype has its own specific axonal membrane receptor (4) (Table 3). The exact characterization of the BTX receptors has not been done until now. The presence of gangliosides GT1b and GD1a is believed to be essential for the functioning and internalization of toxins A and B (27) (Figure 3). 
Table 3: SNARE targets of different botulinum toxin serotypes (4).

\begin{tabular}{l|l}
\hline Toxin & Target \\
\hline A, E & SNAP-25 \\
$B, D, F, G$ & VAMP \\
C & Syntaxin \\
\hline
\end{tabular}

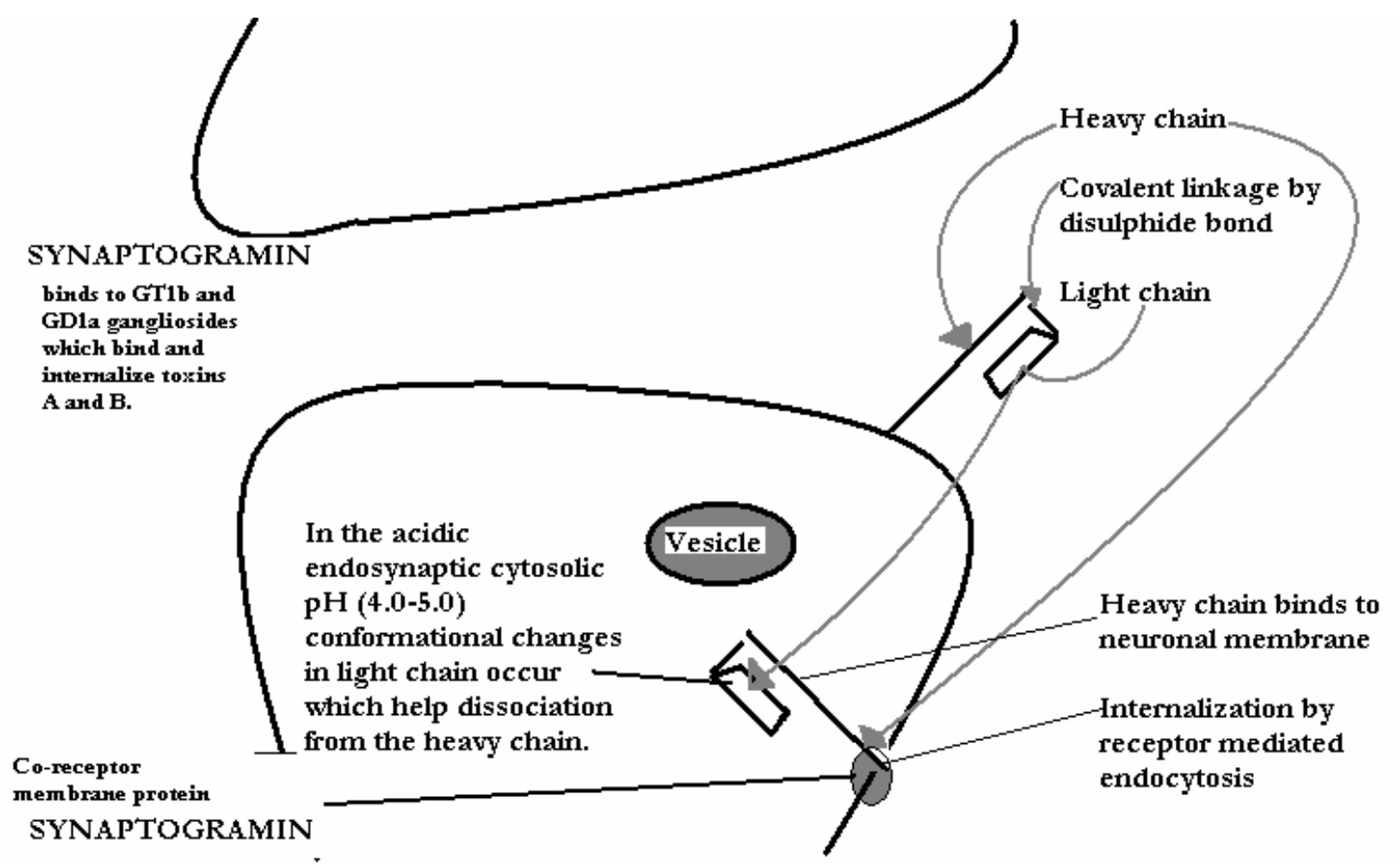

Figure 3: Heavy chain binds to the receptor and once inside the cell the light chain separates at the covalent bond.

A sequence of nine amino acids found in all SNARE proteins is known as SNARE Secondary Recognition (SSR) motif (26). Toxins A and B bind to similar SSR but cleave specific bonds, resulting in proteolysis. The release of other vesicle-bound substances like substance P, Vasoactive Intestinal Peptide (VIP), and neuropeptide $Y$ is also affected. 


\section{INDICATIONS FOR BOTULINUM TOXIN}

It has been used for the treatment of:

- blepharospasm

- glabellar rhytides

- hemifacial spasm

- cervical dystonia

- strabismus

- acquired nystagmus

- oscillopsia

- dry eyes due to the paralysis of the lacrimal pump induced by orbicularis injection.

- hyperlacrimation secondary to aberrant facial nerve regeneration by injection into the lacrimal gland because of inhibition of acetylcholine release at postganglionic nerve ending.

- migraine by using local injection of the toxin, probably through the inhibition of release of vasogenic factors like substance $P$, vasoactive intestinal peptide and neuropeptide $Y$ by the same mechanisms as inhibition of ACh release.

- $\quad$ muscle spasm in upper motor neuron lesions $(2,11,14,15,16,17,25)$.

Doses of botulinum toxin available are expressed in units $(U)$ of biological activity. One unit of toxin equals calculated median intraperitoneal lethal dose $L_{50}$ in female Swiss Webster mice. Variation in $L_{50}$ assay protocols has led to difference in the effects of toxins produced by different manufacturers. The effects of Botox (dose to dose) are more than those of Dysport, which in turn is more potent when compared to Myobloc.

For Botox and Dysport, sterile preservative free saline is used for reconstitution. It must be used with 4 hours of reconstitution. Some authors have advocated the use of preserved saline for reconstitution, in which case the shelf life increases to one month (Table 4). 
Table 4: Commercial preparations

\begin{tabular}{l|l|l}
\hline Preparation & Presentation & Remarks \\
\hline Botox $^{\mathrm{R}}$ & $\begin{array}{l}100 \mathrm{U} \text { of sterile vacuum- } \\
\text { dried solid. Must be kept } \\
\text { at }-5^{\circ} \mathrm{C} .\end{array}$ & $\begin{array}{l}\text { BTX type A. Hall strain of } \\
\text { Clostridium difficile type A }\end{array}$ \\
$\begin{array}{l}\text { Dysport } \\
\text { Fyobloc }\end{array}$ & $\begin{array}{l}\text { Freeze-dried solid. } \\
\text { of } 5000 \text { IU/ml. }\end{array}$ & $\begin{array}{l}\text { BTX type A } \\
\text { BTX type B. Bean strain of } \\
\text { Clostridium difficile type B. }\end{array}$ \\
\hline
\end{tabular}

\section{RECOVERY FROM THE EFFECTS OF TOXIN}

Muscle activity is regained slowly over months after toxin injection. Mechanism of recovery is not fully documented. A reduction in acetylcholine esterase levels leads to increased receptor sensitivity (24). There is upregulation of extrajunctional acetylcholine receptors along with increased lysosomal and endocytic activity, which may contribute to recovery $(1,23)$. In animal studies sprouting of new terminal axons from affected motor nerves has also been seen. The decrease in cross sectional area and density of myofilaments is reversible and resolves within a few months. However in ocular muscles permanent ultrastructural changes occur (9). Depending on the dose and concentration of the toxin used, muscle weakness is produced. This peaks after 2 to 6 weeks and begins to subside after about 10-12 weeks of administration. Full strength may return after 3 to 6 months (3).

\section{COMPLICATIONS OF BOTULINUM TOXIN}

It is generally safe and well tolerated. The most common adverse effect is the extension of the effect outside the intended area (12). This has been attributed to diffusion and difficulty in comparability of doses. Though with lower doses, its effects are not much pronounced, however no satisfactory solution to the problem of diffusion exists at the time of writing. Reports suggest that botulinum toxin $B$ has lesser diffusion rates in animal studies but whether this will have any clinically significant effect in humans remains to be seen. Ptosis and paralytic ectropion hence are common side effects in ocular practice. With larger doses (600-900 $U$ as used in cervical dystonia), generalized weakness has also been reported. The short duration 
of activity of BTX (10-12 weeks) implies automatically that the side effects are also transient and usually self-limiting requiring no more than reassurance. Anaphylaxis and rashes may be encountered occasionally (13).

\section{CONTRAINDICATIONS OF BOTULINUM TOXIN USE}

Any history of neuromuscular disease like myasthenia is an absolute contraindication for BTX use (7). Similarly, concurrent use with drugs that interfere with neuromuscular junction function like aminoglycosides is not recommended (19). Use in pregnancy and lactation is discouraged but no reports of teratogenicity have been made.

\section{REFERENCES}

1. BAMBRICK L., GORDON T. Acetylcholine receptors and sodium channels in denervated and botulinum-toxin-treated adult rat muscle. J. Physiol., 1987, 382, 69-86.

2. BINDER WJ., BRIN MF., BLITZER A., SCHOENROCK LD., POGODA JM. Botulinum toxin type A (BOTOX) for treatment of migraine headaches: an open-label study. Otolaryngol. Head Neck Surg., 2000; 123, 669-76.

3. BRIN MF., FAHN S., MOSKOWITZ C., FRIEDMAN A., SHALE HM., GREENE PE., BLITZER A., LIST T., LANGE D., LOVELACE RE., MCMAHON D. Localized injections of botulinum toxin for the treatment of focal dystonia and hemifacial spasm. Mov. Disord. 1987, 2, 237-54.

4. CALLAWAY JE., AREZZO JC., GRETHLEIN AJ. Botulinum toxin type B: an overview of its biochemistry and preclinical pharmacology. Dis. Mon., 2002, 48, 367-83.

5. DASGUPTA BR. Structure and structure function relation of botulinum neurotoxins. In: LEWIS GE. Ed. Biomedical aspects of Botulism. New York: Academic Press, 1981: 1-19.

6. DASGUPTA BR. The structure of botulinum neurotoxin. In: SIMPSON LL. Ed. Botulinum neurotoxin and Tetanus toxin. San Diego: Academic Press, 1989: 53-67. 
7. ERBGUTH F, CLAUS D, ENGELHARDT A, DRESSLER D. Systemic effects of local botulinum toxin injections unmasks subclinical Lambert-Eaton myasthenic syndrome. J. Neurol. Neurosurg. Psychiatry, 1993, 56, 1235-6.

8. GONNERING RS. Pharmacology of botulinum toxin. Int. Ophthalmol. Clin., 1993, 33, 203-26.

9. HARRIS CP., ALDERSON K., NEBEKER J., HOLDS JB., ANDERSON RL. Histologic features of human orbicularis oculi treated with botulinum A toxin. Arch. Ophthalmol., 1991, 109, 393-5.

10. HAYASHI T., MCMAHON H., YAMASAKI S., BINZ T., HATA Y., SUDHOF TC., NIEMANN H. Synaptic vesicle membrane fusion complex: action of clostridial neurotoxins on assembly. EMBO J., 1994, 13, 5051-61.

11. HELVESTON EM., POGREBNIAK AE. Treatment of acquired nystagmus with botulinum A toxin. Am. J. Ophthalmol., 1988, 106, 584-6.

12. LANGE DJ., BRIN MF., WARNER CL., FAHAN S., LOVELACE RE. Distant effects of local injection of botulinum toxin. Muscle Nerve, 1987, 10, 552-5.

13. LEWITT PA., TROSCH RM. Idiosyncratic adverse reactions to intramuscular botulinum toxin type A injection. Mov. Disorder, 1997, 12, 1064-7.

14. ODERGREN T., HJALTASON H., KAAKKOLA S., SOLDERS G., HANKO J., FEHLING C., MARTTILA RJ., LUNDH H., GEDIN S., WESTERGREN I., RICHARDSON A., DOTT C., COHEN H. A double blind, randomized, parallel group study to investigate the dose equivalence of Dysport and Botox in the treatment of cervical dystonia. J. Neurol. Neurosurg. Psychiatry, 1998, 64, 612.

15. REPKA MX., SAVINO PJ., REINECKE RD. Treatment of acquired nystagmus with botulinum neurotoxin A. Arch. Ophthalmol., 1994, 112, 1320-4.

16. RIEMANN R., PFENNIGSDORF S., RIEMANN E., NAUMANN M. Successful treatment of crocodile tears by injection of botulinum toxin into the lacrimal gland: a case report. Ophthalmology, 1999, 106, 2322-4.

17. SAHLIN S., CHEN E., KAUGESAAR T., ALMQVIST H., KJELLBERG K., LENNERSTRAND G. Effect of eyelid botulinum toxin injection on lacrimal drainage. Am. J. Ophthalmol., 2000, 129, 481-6.

18. SAKAGUCHI G., KOZAKI S., OHISHI I. Structure and function of botulinum toxins. In: ALOUF JE., FEHRENBACh FJ., FREER JH., JELJASZEWICZ J. Eds. Bacterial protein toxins. London: Academic Press, 1984: 435-43. 
19. SANTOS JI., SWENSON P., GLASGOW LA. Potentiation of Clostridium botulinum toxin aminoglycoside antibiotics: clinical and laboratory observations. Pediatrics, 1981, 68, 50-4.

20. SCHANTZ EJ., JOHNSON EA. Botulinum toxin: the story of its development for the treatment of human disease. Perspect. Biol. Med., 1997, 40, 317-27.

21. SCOTT AB. Botulinum toxin injection into extraocular muscles as an alternative to strabismus surgery. Ophthalmology, 1980, 87, 1044-9.

22. SNIPE PT., SOMMER H. Studies on botulinus toxin. Acid precipitation of botulinus toxin. J. Infect. Dis., 1928, 43, 152-60.

23. TAGERUD S., LIBELIUS R., THESLEFF S. Effects of botulinum toxin induced muscle paralysis on endocytosis and lysosomal enzyme activities in mouse skeletal muscle. Pflugers Arch., 1986, 407, 275-8.

24. THESLEFF S., MOLGO J., TAGERUD S. Trophic interrelations at the neuromuscular junction as revealed by the use of botulinal neurotoxins. $J$. Physiol. (Paris), 1990, 84, 167-73.

25. VERHEYDEN J., BLITZER A. Other noncosmetic uses of BOTOX. Dis. Mon., 2002, 48, 357-66.

26. WASHBOURNE P., PELLIZZARI R., BALDINI G., WILSON MC., MONTECUCCO $C$. Botulinum neurotoxin types $A$ and $E$ require the SNARE motif in SNAP-25 for proteolysis. FEBS Lett., 1997, 418, 1-5.

27. YOWLER BC., KENSINGER RD., SCHENGRUND CL. Botulinum neurotoxin A activity is dependent upon the presence of specific gangliosides in neuroblastoma cells expressing synaptotagmin I. J. Biol. Chem., 2002, 277, 32815-9. 